\title{
The Role of Religious Education Teacher Post-Covid- 19: Building Spirituality, In Addition to Religiosity
}

\author{
Esther Idayanti \\ \{estheridayanti@hits.ac.id\} \\ Sekolah Tinggi Teologi Internasional Harvest
}

\begin{abstract}
As pandemic hits hard in families, their children and adolescents face stress as an impact of lockdown, parenting pressure, household chaos, and inability to play with friends. The pandemic has caused stress, anxiety, and depression in children and adolescents both during and after the pandemic. When parents are experiencing stress and other negative emotions, children and adolescents need another source of support such as their religious education teachers at school. Teachers can help students build faith and resilience to face stress during and post-pandemic, as spirituality and religion have been proven to help people cope with stress. However, there is a difference between teaching religion as a course subject and building spirituality. Aside from building religiosity, the teacher also needs to build spirituality. Religiosity is defined as a set of beliefs and knowledge on a specific religion, while spirituality is an interaction with the Divine in day-to-day life. This paper aims to research the role of religious education teachers in building spirituality among children and adolescents to cope with the stress and trauma of the pandemic. Using the literature research method, the writer seeks to explore the role of the teacher, learning methodology, and topics employed when building spirituality in students. The current research focuses on various learning methods in achieving educational goals during the pandemic and the role of religiosity/spirituality in coping with the pandemic. However, there is no discussion on the distinction between teaching religiosity and spirituality. This research will benefit religious education teachers in forming their courses and interactions to develop students' spirituality during and after the pandemic.
\end{abstract}

Keywords: Spirituality; Religiosity; Religious Education; Religion Teacher; Pandemic

\section{Introduction}

COVID-19 has changed the world in a significant way. In order to contain the spread of the virus, the government has implemented various measures such as lockdown and social distancing. In many countries, e.g. Indonesia, schools have been closed for more than a year. Children and adolescents are studying at home and interacting with their friends online. They are experiencing isolation not only from their friends but also with their extended family and the community. They can no longer play outside or spend time on outdoor hobbies. This social 
isolation has caused loneliness in children and adolescents, which has been linked to mental health problems (Loades et al., 2020). In addition, children and adolescents experience fears and uncertainty due to a limited understanding of complex problems such as a pandemic. For instance, they worry about their family's health and whether family members will contact COVID-19 (Jiao et al., 2020).

On the other hand, parents are also not free from problems caused by the pandemic. The pandemic has led to the economic downturn that caused parents to experience a sharp decline in income or even lose their job. Parents who work from home need to assist their children in studying from home and manage the fear and anxiety that constantly linger in the family during this uncertain time. This stressful condition might increase the chance of children maltreatment by parents (Witt, Ordóñez, Martin, Vitiello, \& Fegert, 2020). There is a finding of an increased frequency of anxiety and depression symptoms in children and adolescents, such as poor sleep quality, nightmares, decreasing appetite, physical problems, and clinginess, among other symptoms (Jiao et al., 2020). Like any other disaster, the impact of a pandemic on children and adolescents' mental health will persist during and after the pandemic. Thus, there is a need for outside assistance or intervention for children and adolescents since parents also face stress due to the pandemic.

The current research focuses on spiritual development within a family done by the church or the role of religious education teachers to use various learning methods to teach religion during pandemics. Other papers discuss the synergy between parents and religious education teachers in achieving educational goals during pandemics. However, no research has discussed the role of religious education teachers in nurturing spirituality in students to support them during and after the pandemic. Furthermore, this article differentiates the understanding between teaching religion and building spirituality in students. This paper uses the literature research method to explore the topic. Literature research method is an appropriate tool in seeking an answer, theory, and evidence of a particular topic at hand (Snyder, 2019). Literature reviews provide a deep and broad understanding of the study by extracting information from relevant sources (Xiao and Watson, 2019). To build an understanding of the topic, first, this article will emphasize the importance of spirituality as a coping mechanism in adverse times. Second, it will discuss the strategic role of religious education teachers at school as a means of support for children and adolescents while parents are struggling to survive the pandemic. Third, this paper will provide some practical tips for teachers to build spirituality in the classroom setting, hoping to help teachers achieve the goal of nurturing the spiritual life of children. In this paper, the terms children and adolescents are used interchangeably with the terms students.

\section{Results and Discussion}

\subsection{Spirituality as a Coping Mechanism}

On one side, the pandemic brings fear, anxiety, and stress to children and adolescents. However, on the other side, crisis and traumatic events provide an opportunity for growth and development under the right circumstances. Adversity can benefit people by increasing resilience, creating a sense of ability to manage stressful situations rather than feeling overwhelmed by difficult events. Children and adolescents tend to cope effectively with future adversity (Seery, 2011). Nevertheless, there is an emphasis on the need to nurture children and adolescents in a supportive environment for them to achieve this resilience. One of the most 
significant environments is building an atmosphere of faith and encouraging spirituality (Fernando and Ferrari, 2011).

Several experts emphasize the importance of nurturing spirituality in school as it is proven to improve the well-being of children (De Souza, 2006). Religious beliefs and spirituality serve as a coping mechanism to face challenges in life (Exline, 2002), and provide people with a meaning that helps us overcome the mental crisis. Religion and spirituality become the reference for understanding the meaning of life and providing an explanation for adversity. While some people perceive religiosity and spirituality as interchangeable terms with undistinguishable meaning, others differentiate between the two.

Religiosity refers to doctrinal, denominational, system or worship, social, and behavior shared within a group. On the other hand, spirituality involves a relationship with God (or the transcendent), emphasizing life's meaning, sincere concern for others, and the deep understanding that there is more than just this current physical life (Fetzer Institute, 1999). Spirituality is day-to-day experience with God (Luquis, Brelsford, and Rojas-Guyler, 2012), and it is measured by a person perception of God and His involvement and interaction in daily life (Underwood \& Teresi, 2002).

The distinction between religiosity and spirituality underlines the fact that people can be religious without being spiritual. They can perform the duty of a religion without having a strong relationship with God. Therefore, in a religious education class, students can learn about the religious laws, regulations, and knowing what is expected of them in terms of behavior, while not having a personal relationship with God. In fact, knowledge on religion and diligent religious practice (or religiosity) does not prevent students from not doing the behavior discouraged by religion (Firmiana, Prasetya, and Imawati, 2012). Thus, to support children and adolescents in adversity, religious education teachers need to nurture the spirituality of children, i.e. their relationship with God, and not only teaching the rules, regulations, or doctrines of the religion.

\subsection{The Role of Religious Education Teacher}

During the pandemic, parents are pressured with facing economic challenges, working from home while educating children simultaneously, and accommodating their anxiety. This stressful situation can bring negative consequences to the children (Witt et al., 2020). On some occasions, children and adolescents need outside intervention or help because parents alone cannot bear the burden of the pandemic (Schiavo, 2020). One of the support systems already in place and can be utilized as an outside intervention is religious education teachers in schools. Children and adolescents need a supportive relationship that offers them a safe and encouraging environment during an adverse condition. A model of interaction that religious education teachers can adopt for assisting students in distress is the "Tutor of Resilience" model (ToR). A tutor of resilience is a person who encourages other individuals to cope with stress and become more resilient by utilizing their internal resources and enlarging their capacity (Giordano, Cipolla, and Ungar, 2021).

The function of religious education teachers is not merely transferring knowledge but also fostering the children and adolescents' psychological, mental, and spiritual growth. Teachers serve as motivators to encourage students who are facing discouragement, frustration, and failure to rise and face the challenges (Intarti, 2016). Moreover, religious education teachers can serve as parental figures that provide attachment bonds (Brandt, Fournier, and Mohr, 2009). Therefore, religious education teachers can support children and adolescents as tutors of resilience who motivate them during adversity. Their role is very strategic in facilitating 
students to overcome stress during and post-pandemic. They facilitate personal growth and help students to find internal resources to be resilient.

\subsection{Nurturing Spirituality in Classroom Sessions}

There are some ways teachers can nourish spirituality in a classroom session. For example: helping children to be calm through silence, identifying moments of joy and mystery, facilitating the search of meaning and purpose in life, encouraging the pursuit of wisdom, becoming more aware of "the hand of God" in their lives, and responding to Him in everyday life (De Souza, 2006). More examples are described below.

First, teachers can initiate a more personal conversation with children. Children and adolescents need to express their feelings during stressful times (Imran, Zeshan, and Pervaiz, 2020). Questions such as "How are you feeling?" "What is happening in your family lately?" "How do you feel about being at home all the time?" These questions open a platform for students to share their joy, doubt, excitement, anxiety, loneliness, fear, disappointment, and other emotions.

Second, the teacher can teach them meaningful things in life that are age-appropriate and relevant to children and adolescents. For elementary students, the teacher can ask students to draw something meaningful and let them share it with their friends. The teacher can present questions such as "What is meaningful to you? What do you hold dear in life? What is the most important thing in your life?" These questions will help children to think about things that are important for them $(\mathrm{Ng}, 2012)$. The next step is for the teacher to ask whether there is a real concern from the students about important or meaningful things in their lives. Then, the teacher can ask students to imagine placing those things in the hands of God. For younger children, teachers can ask them to fold their drawings and put them in a special box that the teacher provided. After that, the teacher can lead a special prayer dedicating their most important and meaningful things to the care of God.

Third, the teacher can encourage a moment of silence for them to calm down and relax from time to time. Through this exercise, students can experience the feeling of peace. They learn to cherish the time to relax and slow down $(\mathrm{Ng}, 2012)$. Amid a seemingly chaotic life during and post-pandemic, children need a time to calm down and relax.

Fourth, the teacher can ask children to take their time to say a personal prayer or express their prayer in writing. Prayer is an effective way to cope with a difficult life experience as it expresses deep feelings and helps children to reframe the situation. Prayer is important for psychological reasons, and it is proven to increase a sense of well-being in children. It builds the relationship between the students and God (Mountain, 2005). An understanding that they can connect to a kind and powerful God for things beyond their or their parents' control will bring a sense of ease and relief to children and adolescents.

A social support group that offers encouragement is pivotal to individual mental health (Fetzer Institute, 1999). The teacher can provide support by offering sympathy and encouragement as well as inviting students to encourage one another during the classroom session. The class serves as a social support group in addition to a place of learning. For example, the teacher can encourage children or adolescents to share their stories, especially those with struggles. Then, the teacher can start by giving encouragement such as, "I know you can do it." "I will pray for you this week." Afterward, the teacher can ask other students to give words of support for that particular student who is facing challenges. Words of support have been proven to influence children positively, increase their motivation, performance, and 
self-esteem (Kamins and Dweck, 1999). Encouragement can also be expressed by reading part of a religious holy book (Quran, the Bible, Veda, etc.)

\section{Conclusion}

The pandemic is still ongoing, and some experts predict that we will need to coexist with COVID-19. The pandemic will not stop until the virus no longer finds a transmitter, a human body, as a host. As a result, the whole world needs to be vaccinated to end the pandemic, and this is a difficult requirement to fulfill (Lichfield, 2020)(Lempinen, 2021). Thus, the pandemic and its impacts, such as economic recession, parental stress, and even death resulting from COVID-19, will likely continue. Therefore, children and adolescents need a long-term solution to help them cope with the pandemic's stress. One of the resources is to encourage religious education teachers at school to fill the gaps and become the tutor of resilience by building students' spirituality. During an adverse situation, people spirituality has been proven to be an effective coping mechanism. Religious education teachers should also develop spirituality and not only teach religion. Religiosity refers to theology, a system of doctrine, worship, and behavior, while spirituality emphasizes the relationship between an individual with the Divine. Knowledge will develop the mind, but the relationship will encourage the heart.

\section{References}

[1] Brandt, P.-Y., Fournier, C.-A., and Mohr, S. 2009. "12 Self-Identity and Religion/Spirituality." Religion and Spirituality in Psychiatry, 158.

[2] De Souza, M. 2006. "Educating for Hope, Compassion and Meaning in a Divisive and Intolerant World." International Journal of Children's Spirituality, 11(1), 165-175. https://doi.org/10.1080/13644360500504488

[3] Exline, J. J. 2002). "Stumbling Blocks on the Religious Road: Fractured Relationships, Nagging Vices, and the Inner Struggle to Believe." Psychological Inquiry, 13(3), 182189. https://doi.org/10.1207/S15327965PLI1303_03

[4] Fernando, C., \& Ferrari, M. 2011. "Spirituality and Resilience in Children of War in Sri Lanka." Journal of Spirituality in Mental Health, 13(1), 52-77. https://doi.org/10.1080/19349637.2011.547138

[5] Fetzer Institute. 1999. National Institute on Aging Working Group: Multidimensional Measurement of Religiousness, Spirituality for Use in Health Research. Kalamazoo, MI. Retrieved from https://fetzer.org/resources/multidimensional-measurementreligiousnessspirituality-use-health-research

[6] Firmiana, M. E., Prasetya, M. R., and Imawati, R. 2012. Ketimpangan Relijiusitas dengan Perilaku: Hubungan Religiusitas dengan Perilaku Seksual Pra Nikah Remaja SMA/Sederajat di Jakarta Selatan. Jurnal Al-Azhar Indonesia Seri Humaniora, 1(4), 239-245. http://dx.doi.org/10.36722/sh.v1i4.80

[7] Giordano, F., Cipolla, A., and Ungar, M. 2021. Tutor of Resilience: A Model for Psychosocial Care Following Experiences of Adversity. Frontiers in Psychiatry, 12, 351. https://doi.org/10.3389/fpsyt.2021.559154

[8] Imran, N., Zeshan, M., and Pervaiz, Z. 2020. "Mental Health Considerations for Children and Adolescents in COVID-19 Pandemic." Pakistan Journal of Medical 
Sciences, 36(COVID19-S4), S67. https://doi.org/10.12669/pjms.36.COVID19-S4.2759

[9] Intarti, E. R. 2016. "Peran Guru Pendidikan Agama Kristen Sebagai Motivator." REGULA FIDEI: Jurnal Pendidikan Agama Kristen, 1(2), 28-40.

[10] Jiao, W. Y., Wang, L. N., Liu, et al. 2020. "Behavioral and emotional disorders in children during the COVID-19 epidemic." The Journal of Pediatrics, 221, 264. https://doi.org/10.1016/j.jpeds.2020.03.013

[11] Kamins, M. L., \& Dweck, C. S. 1999. Person Versus Process Praise and Criticism: Implications for Contingent Self-worth and Coping. Developmental Psychology, 35(3), 835. https://doi.org/10.1037/0012-1649.35.3.835

[12] Lempinen, E. 2021. After Covid-19, Work will Never be "Normal" Again. Retrieved May 21, 2021, from https://news.berkeley.edu/2021/03/09/after-covid-19-work-willnever-be-normal-again/

[13] Lichfield, G. 2020. "We're not Going Back to Normal." Retrieved May 21, 2021, from https:/www.technologyreview.com/2020/03/17/905264/coronavirus-pandemic-socialdistancing-18-months/

[14] Loades, M. E., Chatburn, E., Higson-Sweeney, et al. 2020. "Rapid Systematic Review: The Impact of Social Isolation and Loneliness on the Mental Health of Children and Adolescents in the Context of COVID-19." Journal of the American Academy of Child \& Adolescent Psychiatry, 59(11), 1218-1239. https://doi.org/10.1016/j.jaac.2020.05.009

[15] Luquis, R. R., Brelsford, G. M., and Rojas-Guyler, L. 2012. "Religiosity, Spirituality, Sexual Attitudes, and Sexual Behaviors Among College Students." Journal of Religious Health, 51, 601-614. https://doi.org/10.1007/s10943-011-9527-z

[16] Mountain, V. 2005. "Prayer is a Positive Activity for Children - a Report on Recent Research." International Journal of Children's Spirituality, 10(3), 291-305. https://doi.org/10.1080/13644360500347573

[17] Ng, Y.-L. 2012. "Spiritual Development in the Classroom: Pupils' and Educators' Learning Reflections." International Journal of Children's Spirituality, 17(2), 167185.

[18] Schiavo, R. 2020. "Children and COVID-19: Addressing the Mental Health Impact of the Pandemic." Journal of Communication in Healthcare, 13(3), 147-150. DOI: 10.1080/17538068.2020.1821438

[19] Seery, M. D. 2011. "Resilience: A Silver Lining to Experiencing Adverse Life Events?" Current Directions in Psychological Science, 20(6), 390-394.

[20] Snyder, H. 2019. "Literature Review as a Research Methodology: an Overview and Guidelines." Journal of Business Research, 104, 333-339.

[21] Underwood, L. G., and Teresi, J. A. 2002. "The Daily Spiritual Experience Scale: Development, Theoretical Description, Reliability, Exploratory Factor Analysis, and Preliminary Construct Validity Using Health-Related Data." Annals of Behavioral Medicine, 24(1), 22-33. https://doi.org/10.1207/S15324796ABM2401_04

[22] Witt, A., Ordóñez, A., Martin, A., Vitiello, B., and Fegert, J. M. (2020). "Child and Adolescent Mental Health Service Provision and Research During the Covid-19 Pandemic: Challenges, Opportunities, and a Call for Submissions." Child and Adolescent Psychiatry and Mental Health, 14, 19. https://doi.org/10.1186/s13034-02000324-8

[23] Xiao, Y., \& Watson, M. 2019. "Guidance on Conducting a Systematic Literature Review." Journal of Planning Education and Research, 39(1), 93-112. https://doi.org/10.1177/0739456X17723971 